\title{
Research on Computer Aided English Teaching Mode
}

\author{
Huahong Rao ${ }^{1}$ \\ ${ }^{1}$ Tongren University, Tongren, Guizhou, 554300 \\ 346591653@163.com
}

KEYWORDS: Computer Aided English; Teaching Mode

\begin{abstract}
With the globalization of economic development and the needs of social life, English has increasingly become a global communication tool. In the past the traditional teaching model cannot meet the needs of a good social development. Schools should make full use of multimedia and network technology, the introduction of new teaching model to improve the original single teacher taught based classroom teaching. The new model should be based on modern information technology, especially network technology support, to make English teaching from time and place restrictions, towards personalized learning, autonomous learning direction.
\end{abstract}

\section{Introduction}

In recent years, more and more people realize that the "learner autonomy is the ultimate goal of education" (Brooks \& Grundy, 1988), at the same time, the development of computer network technology to foster learning ability of students to provide a broader and more possible prospects. So we decided to take advantage of computer networks, to enable students to expand the network of independent learning in the classroom. However, taking into account the present stage of Chinese college students have adapted to the teacher-dominated traditional teaching mode, self-learning ability is low, so we let the students in teaching a "guiding constrained independent study", by the teacher's guidance and appropriate constraints to gradually increase the learner's self-learning ability, and gradually transition to the students completely autonomous learning.

English teaching reform is imperative. In the "English course standard" national basic education that "the focus of a new round of English curriculum reform is to change the course too much emphasis on English grammar and vocabulary knowledge to explain and teach, ignoring the tendency of students' practical language skills training, emphasizing courses from the student's interest in learning, life experiences and cognitive level, advocacy experience, practice, participation, cooperation and exchange of learning and task-based teaching approach, the development of students' comprehensive ability to use language, make language learning process as a student the formation of positive emotional experience, active thinking, bold in practice, cultural awareness and the formation of autonomous learning ability. "By learning the standards, we can conclude that, how to mobilize the enthusiasm of students to improve students 'English language proficiency through a variety of teaching approach, accumulation, building knowledge architecture students' English curriculum, English educators important task.

\section{Traditional English Teaching Mode}

Traditional classroom teaching face to digest and consolidate the network content-based self-study and classroom emphasize language output. In a traditional classroom, we have 
strengthened the detection of the effect of self-learning, self-learning in order to ensure that students achieve the desired learning outcomes and urge students to develop good self-study habits. In addition, through listening, speaking, reading, writing and presentation skills to interpret, explain and apply, and enhance student self-initiative in the use of learning strategies awareness, the ability of students to use learning strategies in the self-study. Teachers often guide students to discover the purpose of writing the article, the authors, the way, the implied meaning, etc., to encourage students to ask questions, to think, to explore the connotation of the article and to express their views and evaluation, in order to cultivate the students' ability to think independently.

\section{College English Teaching}

Teaching English in design should be fully highlight the dominant position of students, teachers organize and guide in the teaching process, help students construct knowledge architecture. To this end, the author of the actual college English teaching, teaching should be considered in particular the full application of constructivist teaching philosophy, and make full use of multimedia aids, and combined with other teaching methods Activating English Teaching, in order to most good teaching effect.

English Teaching Patterns should break the original model, it should be combined organically speaking and writing, is no longer the main classroom teacher as a professor, so that students freed from passive learning, like English, loves English, excitation Students' interest in learning English, under the guidance of active interest in learning English, to build their own knowledge of English architecture. English teaching should be student-centered, how to improve students' attitude towards English, is needed to solve a problem. Learning English, we first need to change the teachers' point of view, the liberation of students.

\section{Select the Computer-aided English Teaching Methods}

English teaching classroom atmosphere is very important to make the initiative more students in the classroom and teachers need to create a favorable external environment, teaching, so that students integrate into the English teaching environment, and truly become the subject of teaching.

Traditional English teaching, teachers are more likely to explain the main, student records, and the atmosphere is relatively boring. By means of computer-assisted instruction, we can fully mobilize the initiative of students from the visual, auditory and other media, and tap the knowledge of teaching content.

Computer Assisted Instruction (CAI) is a modern teaching methods computer-aided instruction, can show relevant content, giving students a very intuitive impression image. Through the rational design of teachers teaching, speaking and writing can be organic combination, reflecting the diversity. In the aid of a computer, select some new form of knowledge demonstrated in front of the students, to stimulate student interest in learning. In some areas, you can also reflect the fun, once enrich the teaching content, students will be able to truly think independently, students have interest, the dominant position will be reflected in change from passive learning to active learning.

Computer-aided teaching methods usually get a strong reaction of students in English teaching, the multimedia teaching than the traditional teaching model has obvious advantages. But for different English teaching, there should be a different computer-aided teaching methods scene design. Teachers can use a computer to implement a two-way interactive teaching in English teaching, let the computer to provide high quality and timely feedback, through the man-machine dialogue and other forms, to keep abreast of each student's learning. Students with human-machine 
communication when the computer through suggestive questioning, strengthen the capacity of independent learning active thinking by students to think, discuss, practice and feedback in the form of fast, to truly improve the quality of teaching.

In addition, teachers can through multimedia projectors, etc. in English teaching, writing on the blackboard to save time. By extending the video and audio and other image data, expanding the amount of knowledge of English, increase situational teaching and student practice time, increase interest and reduce the difficulty of teaching, improve teaching quality and efficiency. However, many teachers use computer-aided tools often occur when a misunderstanding, the use of multimedia teaching not to use multimedia away use, but for curriculum design services, should become part of the curriculum is to tap the initiative of student learning, reproduce knowledge of context, "activated" knowledge, to enable students to understand the initiative to carry out, think and communicate through English as their "mother tongue." Therefore, when using the computer-assisted instruction should also pay attention to choose the means and thus better play the advantages of computer-assisted teaching methods.

\section{The Implementation Measures of Computer-Assisted English Teaching Mode}

We are fully applied in the teaching of modern network technology, carefully selected VOA, CNN, AP, NPR and other radio and television programs, film clips as a supplement to hearing material from the English newspapers and magazines at home and abroad selection of articles to supplement reading materials, and with the teachers design their own forms of exercise. A large number of long-term use of authentic materials as teaching material to enable students to contact with modern, idiomatic English, to improve the students 'interest in learning English, and thus improve the students' English proficiency.

Computer network technology to provide students with an unprecedented opportunity to communicate with native speakers of English to communicate, but English native speakers of communication, for students learning English will play a very important role. Therefore, I look for American high school students for students as pen pal, let them communicate and exchange e-mail and through the true sense of the English native speakers. Most students have a pen pal (over 90\%) consider and mail pen pal exchanges help to learn authentic English expression, understand the differences between Chinese and Western culture, increase interest in learning English and English.

A study determined by the teacher has some challenging task, and then divided into several sub-tasks, and provide students with some help students complete tasks prior to pick a good network resources, so that students in certain driving tasks carried out Independent inquiry learning. The final results will be explored in the form of written and verbal statements expressed and evaluated in accordance with the evaluation criteria laid down in advance. It is to allow students to experience the thought process of some of the more experienced learners experience to help those students who temporarily cannot simply their ability to complete the task, the resources to provide some help for them to provide support in the form of a stent, making it eventually formed independently without help fight a complex tasks.

\section{Conclusion}

Computer-assisted language teaching mode, and traditional single teaching mode compared to a more effective teaching. It provides teachers with a new teaching platform, so that teachers update teaching ideas and teaching methods, active use of advanced teaching techniques, some teaching activities conducted in the past in single teaching mode difficult for students to learn to open up 
more channels, enrich students' learning content, and to improve students' interest in learning English, mobilize the initiative of students learning English, students of English learning ability, to improve students' English proficiency.

\section{REFERENCE:}

[1] Chou, S. \& Liu, C. Learning effectiveness in a Web-based Virtual learning environment: a learner control perspective [J]. Journal of Computer Assisted Learning, 2005, 21, 65-76.

[2] Clark R.E. Media will never influence learning [J].Educational Technology Research and Development, 1994, 42: 21-29.

[3] Dodge, B. (1995). Web quests: A technique for Internet-based Learning [J]. Distance Educator, 1995, 1(2), 10-13.

[4] Kern, R. \& M. Warschauer. Introduction: Theory and practice of network-based language teaching [A]. In M. Warschauer \& R. Kern(eds.). Networked-based Language Teaching: Concepts and Practice[C]. Cambridge: Cambridge University Press, 2000.

[5] Williams M.D. Learner-control and instructional technologies [C]. New York: Simon and Schuster Macmillan, 1996. 